\title{
Protocol
}

\section{Rapid Isolation of Nuclei from Cells In Vitro}

\author{
Arash Nabbi ${ }^{1}$ and Karl Riabowol ${ }^{1,2,3}$ \\ ${ }^{1}$ Department of Biochemistry and Molecular Biology, Faculty of Medicine, University of Calgary, Calgary, Alberta \\ T2N 4N1, Canada; ${ }^{2}$ Department of Oncology, Faculty of Medicine, University of Calgary, Calgary, Alberta \\ T2N 4N1, Canada
}

This protocol presents a rapid, efficient, and practical (REAP) method to separate nuclei from cultured cells in vitro with as little damage and contamination as possible. The REAP procedure is performed at low temperature and takes $<2 \mathrm{~min}$, which minimizes protein degradation, protein modification, and diffusion of soluble proteins out of the nuclear compartment while maintaining the integrity of protein complexes. A mild detergent, NP-40, is used together with mild mechanical shearing to disrupt the plasma membrane, leaving the nuclear membrane intact. The REAP method can be used with various cell lines grown in vitro and requires minimal optimization. The isolated nuclei are suitable for numerous downstream applications (e.g., western blotting, 2D gel electrophoresis, and immunoprecipitation). If desired, aliquots of whole-cell lysate and the cytoplasmic fraction can be saved for comparison.

It is essential that you consult the appropriate Material Safety Data Sheets and your institution's Environmental Health and Safety Office for proper handling of equipment and hazardous materials used in this protocol.

RECIPES: Please see the end of this protocol for recipes indicated by $<R>$. Additional recipes can be found online at http://cshprotocols.cshlp.org/site/recipes.

\section{Reagents}

Antipain (optional; see Step 5)

Aprotinin (optional; see Step 5)

Cell line of interest

Growth media appropriate for cell line of interest

Laemmli sample buffer $(4 \times)<\mathrm{R}>$

Leupeptin (optional; see Step 5)

MG132 (optional; see Step 2)

NP-40 (0.1\%) in phosphate-buffered saline (PBS) (ice-cold)

Dissolve the NP-40 in PBS at room temperature (it dissolves faster at room temperature than on ice). Vortex to ensure that the NP-40 is completely dissolved. Store the $0.1 \% N P-40$ solution at $4^{\circ} \mathrm{C}$ until use.

PBS (1×, pH 7.4) (ice-cold) $<\mathrm{R}>$

Phenylmethylsulfonyl fluoride (PMSF) (optional; see Step 5)

RIPA-SDS buffer (if using the nuclei for immunoprecipitation; see Step 11) $<\mathrm{R}>$

\footnotetext{
${ }^{3}$ Correspondence: karl@ucalgary.ca

(C) 2015 Cold Spring Harbor Laboratory Press

Cite this protocol as Cold Spring Harb Protoc; doi:10.1101/pdb.prot083733
} 
A. Nabbi and K. Riabowol

\section{Equipment}

Boiling water bath

Cell culture dishes $(10-\mathrm{cm})$

Cell scraper

Ice bath

Microcentrifuge tubes (1.5-mL)

Micropipette with P1000 tip (see Step 6)

Sonicator

Tabletop microcentrifuge

Vacuum aspirator

This protocol assumes that the isolated nuclei will be used for SDS-PAGE and western blotting, but notes for preparing nuclei for immunoprecipitation are also included.

Modifications can be made for nonadherent cells (e.g., blood cells or suspension cell cultures). For example, the scraping step (Step 3) is not required. The cells must be washed with ice-cold PBS (as in Step 2), but the cells should be centrifuged briefly before aspiration.

1. Grow the cell lines of interest in 10 -cm cell culture dishes until they are $90 \%$ confluent $\left(\sim 1 \times 10^{5}-\right.$ $1 \times 10^{6}$ cells/dish, depending on the cell type).

2. On the day of isolation, aspirate the culture medium, and then wash the cells with ice-cold PBS. Aspirate the PBS.

If studying proteins with a very short half-life, include proteasome inhibitors (e.g., MG132) in the PBS in Steps 2 and 3. The typical concentration of MG132 is $10 \mu \mathrm{M}$, but this can be varied for cell type.

3. Place the culture dish on ice, and scrape the cells off of the plate using $1 \mathrm{~mL}$ of PBS. Transfer the cells to a $1.5-\mathrm{mL}$ microcentrifuge tube on ice.

4. Centrifuge briefly for 5-10 sec at 10,000 rpm (i.e., perform a "pop spin" to pellet the cells).

5. Remove the supernatant by aspiration, and resuspend the cell pellet of $\sim 100-200 \mu \mathrm{L}$ in $900 \mu \mathrm{L}$ of ice-cold PBS containing $0.1 \%$ NP-40.

If examining proteins that are sensitive to proteolysis, include protease inhibitors in the $0.1 \%$ NP-40 solution. We recommend using PMSF (1 mM) along with leupeptin, antipain, and aprotinin ( $2 \mu \mathrm{g} / \mathrm{mL}$ each).

6. Triturate the cell suspension five times on ice with a P1000 micropipette tip.

7. If desired, transfer $300 \mu \mathrm{L}$ of the lysed cell suspension to a new tube (this is the whole-cell lysate). Add $100 \mu \mathrm{L}$ of $4 \times$ Laemmli sample buffer, and mix. Keep on ice until sonication step.

This aliquot of whole-cell lysate contains $\sim 25 \%$ of the total protein in the sample.

If protein quantification is needed, take an aliquot before adding the $4 \times$ Laemmli sample buffer. The aliquot may be stored at $-80^{\circ} \mathrm{C}$ without Laemmli sample buffer if the protease inhibitor cocktail was added to the $0.1 \%$ NP-40 solution in Step 5.

In case of immunoprecipitation, keep the whole call lysate on ice until sonication step.

8. Centrifuge the remaining lysed cell suspension $(700-800 \mu \mathrm{L})$ for $5-10 \mathrm{sec}$ at $10,000 \mathrm{rpm}$.

9. If desired, transfer $300 \mu \mathrm{L}$ of the supernatant to a new tube (this is the cytoplasmic fraction). Add $100 \mu \mathrm{L}$ of $4 \times$ Laemmli sample buffer, and mix. Boil for $1 \mathrm{~min}$. Return to ice or store at $-20^{\circ} \mathrm{C}$.

This aliquot contains about $25 \%$ of the total protein in the cytoplasmic fraction of the sample.

10. Discard the remaining supernatant. Resuspend the pellet in $1 \mathrm{~mL}$ of PBS containing $0.1 \%$ NP-40. Include protease inhibitors in the $0.1 \%$ NP-40 solution if examining proteins that are sensitive to proteolysis. 
11. Centrifuge for 5-10 sec at 10,000 rpm. Discard the supernatant.

The pelleted nuclei should appear white, compared with yellowish pellets of whole cells. At this stage, the pellet can be stored for up to XX mo at $-80^{\circ} \mathrm{C}$.

The isolated nuclei are suitable for multiple applications (e.g., western blotting, 2D gel electrophoresis, or immunoprecipitation). To prepare the sample for SDS-PAGE (e.g., in preparation for western blotting), proceed to Step 12. To prepare the sample for immunoprecipitation, resuspend the pellet in 500-1000 $\mu \mathrm{L}$ of RIPA-SDS buffer optionally with protease inhibitors, sonicate on ice (for sonication details, see Step 13), centrifuge in a microcentrifuge at $4^{\circ} \mathrm{C}$ for $1 \mathrm{~min}$, and transfer the supernatant (which will be used for immunoprecipitation) to a fresh microcentrifuge tube. If necessary, store the supernatant at $-20^{\circ} \mathrm{C}$ before carrying out the immunoprecipitation procedure. Freezing supernatant for coimmuniprecipitation study is not recommeded.

To isolate histones and chromatin from the nuclei, $0.3 \mathrm{~m} \mathrm{KCl}$ works well to remove bound proteins. For more details on this procedure, refer to Schnitzler (2001).

12. Resuspend the pellet in $150 \mu \mathrm{L}$ of $1 \times$ Laemmli sample buffer (this is the nuclear fraction). This sample contains $\sim 75 \%$ of the nuclear proteins.

13. Sonicate the whole-cell lysate (from Step 7) and the nuclear fraction briefly while on ice.

Sonication settings can be varied depending on the equipment. In case of a sonicator with the frequency of $20 \mathrm{kHz}, 2$ pulses, $8 \mathrm{sec}$ each is enough. (A microtip probe should be used that has very high amplitude value and can vibrate up to $150 \mu \mathrm{m}$.) Keep the samples on ice after each pulse to cool down before the next pulse.

14. Boil the nuclear fraction and whole call lysate for $1 \mathrm{~min}$.

15. Store the samples at $-20^{\circ} \mathrm{C}$ until use.

If comparing the relative amounts of particular proteins in the whole-cell lysate, cytoplasmic fraction, and nuclear fraction, the ratio of volumes to load onto the gel is $\sim 18: 18: 6$ (i.e., $18 \mu \mathrm{L}$ of the whole-cell lysate, 18 $\mu L$ of the cytoplasmic fraction, and $6 \mu L$ of the nuclear fraction).

The major strength of the REAP method is that it is rapid, allowing for the isolation of nuclei from cell culture with minimal protein degradation, modification, or loss. Previously, we tested the efficiency of this method on various types of cell lines, including epithelial cells, cancer cells, and fibroblasts (Suzuki et al. 2010). The cytoplasmic and nuclear fractions were pure, as shown by the absence of cross-contamination using cytoplasmic and nuclear marker proteins (e.g., $\alpha$-tubulin and lamin A, respectively). As with other methods of subcellular fractionation, it is difficult to completely avoid cross-contamination, and the levels of contamination are likely to vary somewhat among experiments. Similarly, nuclear damage is inevitable in such procedures. However, to our knowledge, REAP is one of the best methods to obtain an intact nuclear fraction with minimal contamination.

When using detergents such as NP-40, the extent of purity and yield is proportional to the time of incubation as well as the concentration of the detergent. Previously, 0.5\% NP-40 was suggested as an alternative to Potter homogenization for the isolation of nuclei from HeLa cells (Zylber and Penman 1971). However, when using 0.5\% NP-40, we observed contamination of the cytoplasmic fraction due to the breakage/dissolution of nuclear membranes (Suzuki et al. 2010). Thus, to obtain cleaner nuclear and cytoplasmic fractions, we keep the lysates on ice, avoid incubating for long periods of time in the presence of NP-40, and use a lower concentration of the detergent $(0.1 \%)$ that is still sufficient to remove the majority of cytoplasmic membranes.

Attempts have also been made to isolate nuclei with different nonionic detergents. For example, Triton X-100 was used for the preparation of nuclei from tissue (the cat brain cortex) and was reported to yield intact nuclei (Hadjiolov et al. 1965). We have also modified the REAP protocol, using $0.05 \%$ NP-40 and $0.05 \%$ Tween 20 (instead of $0.1 \%$ NP-40) to study nuclear protein interactions (Scott et al. 2001). Triton X-100 is structurally very similar to NP-40; it differs by the number of carbon residues in the side chain. Although it worked well for initial studies, it was reported to increase nuclease activity to a significant extent (Rickwood et al. 1997). Therefore, while Triton X-100 can be used for protein studies, its use should be avoided in studies of nuclear RNA or chromatin. It is worth 
A. Nabbi and K. Riabowol

noting that various types of nuclei show differential sensitivity to detergents, and further optimization of the protocol may be beneficial when using a new cell type.

\section{RECIPES}

Laemmli Sample Buffer (4×)

$\begin{array}{lr}\text { Tris }(1.0 \mathrm{M}, \mathrm{pH} 6.8) & 10 \mathrm{~mL} \\ \text { SDS } & 4.0 \mathrm{~g} \\ \text { Glycerol } & 20 \mathrm{~mL} \\ \beta \text {-Mercaptoethanol } & 10 \mathrm{~mL} \\ \text { Bromophenol blue } & 0.1 \mathrm{~g} \\ \mathrm{dH}_{2} \mathrm{O} & \text { to } 50 \mathrm{~mL}\end{array}$

Phosphate-Buffered Saline (PBS)

Final

Amount to add

Reagent (for $1 \times$ solution)

$\mathrm{NaCl}$

$\mathrm{KCl}$

$\mathrm{Na}_{2} \mathrm{HPO}_{4}$ $\mathrm{KH}_{2} \mathrm{PO}_{4}$ concentration

$(1 \times)$

$8 \mathrm{~g}$

$0.2 \mathrm{~g}$

$1.44 \mathrm{~g}$

$0.24 \mathrm{~g}$

$137 \mathrm{~mm}$

$2.7 \mathrm{~mm}$

$10 \mathrm{~mm}$

$1.8 \mathrm{~mm}$
Amount to add

(for $10 \times$ stock)

Final

concentration $(10 \times)$

\section{$1.37 \mathrm{M}$}

$27 \mathrm{~mm}$

$2 \mathrm{~g} \quad 27 \mathrm{~mm}$

$14.4 \mathrm{~g} \quad 100 \mathrm{~mm}$

$2.4 \mathrm{~g} \quad 18 \mathrm{~mm}$

If necessary, PBS may be supplemented with the following:
$\mathrm{CaCl}_{2} \cdot 2 \mathrm{H}_{2} \mathrm{O}$
$0.133 \mathrm{~g}$
$1 \mathrm{~mm}$
$1.33 \mathrm{~g}$
$10 \mathrm{~mm}$
$\mathrm{MgCl}_{2} \cdot 6 \mathrm{H}_{2} \mathrm{O}$
$0.10 \mathrm{~g}$
$0.5 \mathrm{~mm}$
$1.0 \mathrm{~g}$
$5 \mathrm{~mm}$

PBS can be made as a $1 \times$ solution or as a $10 \times$ stock. To prepare $1 \mathrm{~L}$ of either $1 \times$ or $10 \times \mathrm{PBS}$, dissolve the reagents listed above in $800 \mathrm{~mL}$ of $\mathrm{H}_{2} \mathrm{O}$. Adjust the $\mathrm{pH}$ to 7.4 (or 7.2, if required) with $\mathrm{HCl}$, and then add $\mathrm{H}_{2} \mathrm{O}$ to $1 \mathrm{~L}$. Dispense the solution into aliquots and sterilize them by autoclaving for $20 \mathrm{~min}$ at 15 psi $\left(1.05 \mathrm{~kg} / \mathrm{cm}^{2}\right)$ on liquid cycle or by filter sterilization. Store PBS at room temperature.

\section{RIPA-SDS Buffer}

$10 \mathrm{~mm}$ Tris (pH 7.4)
$150 \mathrm{~mm} \mathrm{NaCl}$
$10 \mathrm{~mm} \mathrm{KCl}$
$1 \mathrm{~mm} \mathrm{EDTA}$
$0.5 \%$ deoxycholic acid
$0.5 \%$ Tween 20
$0.5 \% \mathrm{NP}-40$
$0.1 \%$ SDS

\section{REFERENCES}

Hadjiolov AA, Tencheva ZS, Bojadjieva-Mikhailova AG. 1965. Isolation and some characteristics of cell nuclei from brain cortex of adult cat. J Cell Biol 26: 383-393.

Rickwood D, Messent A, Patel D. 1997. Isolation and characterization of nuclei and nuclear subfractions. In Subcellular fractionation: A practical approach (ed. Graham JM, Rickwood D), pp. 71-105. Oxford University Press, Oxford.

Schnitzler GR. 2001. Isolation of histones and nucleosome cores from mammalian cells. Curr Protoc Mol Biol Chapter 21:Unit 21.5. doi: 10.1002/ 0471142727.mb2105s50.
Scott M, Bonnefin P, Vieyra D, Boisvert FM, Young D, Bazett-Jones DP, Riabowol K. 2001. UV-induced binding of ING1 to PCNA regulates the induction of apoptosis. J Cell Sci 114: 3455-3462.

Suzuki K, Bose P, Leong-Quong RY, Fujita DJ, Riabowol K. 2010. REAP: A two minute cell fractionation method. BMC Res Notes 3: 294.

Zylber EA, Penman S. 1971. Products of RNA polymerases in HeLa cell nuclei. Proc Natl Acad Sci 68: 2861-2865. 


\section{Rapid Isolation of Nuclei from Cells In Vitro}

Arash Nabbi and Karl Riabowol

Cold Spring Harb Protoc; doi: 10.1101/pdb.prot083733

\begin{tabular}{cc}
\hline $\begin{array}{r}\text { Email Alerting } \\
\text { Service }\end{array}$ & Receive free email alerts when new articles cite this article - click here. \\
\hline $\begin{array}{c}\text { Subject } \\
\text { Categories }\end{array}$ & $\begin{array}{c}\text { Browse articles on similar topics from Cold Spring Harbor Protocols. } \\
\text { Cell Biology, general (1382 articles) } \\
\text { Preparation of Cellular and Subcellular Extracts (104 articles) } \\
\text { Subcellular Fractionation (88 articles) }\end{array}$ \\
\hline
\end{tabular}

